\title{
衝突を用いた多リンクマニピュレータの安定制御
}

\author{
正司康 雅* 稲葉 忠* 福田敏男** 細 貝 英実***
}

\section{Stable Control of Multi-link Manipulator Using Collision Phenomena}

\author{
Yasumasa SHOJI Makoto INABA Toshio FUKUDA \\ Hidemi HOSOKAI
}

In this paper, a methodology using the Lyapunov direct method is proposed to analyze the stability of a multi-link manipulator system which is positioned on a flexible wall with collision phenomenon. The stability and response of the system are examined by parameter studies of numerical simulation. As the demands for rapid motion of robotics has been increasing in the field of industry to achieve higher efficiency, collision has become a problem to be solved, because every task includes contact when manipulator acts on an object. However, few researches have been undertaken to overcome this problem. In this paper, we employ a Hertz-type model with energy loss parameter to express the impact force between the manipulator and the wall. Using this model, we proved the stabilization effect of collision using the Lyapunov method. The effect is confirmed by the simulation. As a result, stable positioning of the manipulator on the flexible wall is assured and use of collision is sometimes effective to control manipulator to do a task with rapid contact to environment.

Key Words : Collision, Multi-link Manipulator, Stability, Lyapunov Method, Simulation

\section{1. は じめに}

近年のロボットに関する研究はめざましい.これは, あらゆる分野においてロボットに対する必要性が生じて きたためである. また，これらの研究が実際のマニピュ レータなどロボットに応用されるだけの計算機等のハー ドウェアや，新しい理論に基づくアルゴリズムなどのソ フトウェアが現状でも確立されつつある為である.

一方，口ボットに対する要求は，FA 工場などで高効 率性を実現するための高速性や，宇宙ロボットや極限作 業ロボットなどで現われるようないろいろな作業をこな す多様性に対するものも含んでいる，ところが，口ボッ トに何らかの作業を行わせると，環境例えば対象物との 間で必ず相互作用が生じる4). この相互作用は高速化に 伴い衝突現象になって制御を困難にし，時には制御系の

原稿受付 1991 年 1 月 29 日

*東洋エンジニアリング株式会社 *** 東京理科大学

JRSJ Vol. 9 No. 5
挙動を不安定にすることもある5). また，衝突を含んだ 制御に関する研究は少なく; 衝突に関する研究は衝突回 避が主なテーマとなっている.これは, 衝突が構造自体 の変化を伴う非線形性の強い現象であることが理由の一 つとして挙げられる．また，現象が非常に速いというの も制御を難しくしている理由の一つである.ただ，物理 現象として捉えた場合, 衝突はエネルギー損失を伴う現 象であり，系の挙動に関しては安定化作用を持つとも考 えられる、これは、磁気ばね吸振器のよらな形で実現す ることが出来る6). しかも， ロボットの高速化を考える と，接触を含む動作，例えば把持などを速くすることが 必要であり, 制御系においても衝突を含む制御は, ブレ ークスルーの必要な解決すべき問題となってきている.

そこで，いままで筆者らは，直線上を運動する 1 自由 度マニピュレータの衝突について 報告1,2) してきたが，

本論文では衝突を含むマニピュレータの制御について多 リンク型のマニピュレータを対象として，これを壁の表 面で止める問題を考える.これは，接触時に衝突を生じ 
ないようにするには, マニピュレータ先端位置の計測に 誤差が生じるため, リアルタイムで制御するには難しい 問題となるが, 衝突を許容するかもしくは逆に衝突を利 用するようにすれば, 比較的容易な問題になる可能性が ある. 特にフレキシブルアームなどでは, かなり制御に かかる負担を減らすこともできる、ただしここでは問 題を簡単化するために, 平面内の位置決め制御を行なら のに充分な自由度を有する 2 リンクマニピュレータに着 目した.この非線形なマニピュレータの非線形運動の制 御問題について, まずリアプノフの方法による安定性の 検討を行った。また, 実際の制御では安定性が保証され ていることと共に, 要求通りの応答性を持つことも重要 である.この応答性を検討するためにシミュレーション を用いたパラメータスタディを行った.

本論文では, 衝突を含む多リンク系は非線形システム として表現できるが，このシステムもフィードバック制 御によって安定に制御でき,また制御系の安定化のため に衝突を積極的に利用することもできることを示す.

\section{2. カ学モデルと運動方程式}

安定性の検討と数値シミュレーションを行うために Fig.1のように2 リンクのマニピュレータが变形可能な 壁に衝突するような力学モデルを考える.

\section{1 仮 定}

このモデルでは次のような仮定を設けた.

仮定 1. マニピュレータは剛体のリンクをジョイントで つないだ形で表す．このとき，リンク系の質量について は, 簡単のためにすべて各リンク先端部のジョイントま たはポインターに存在するものとする.

仮定 2. 各ジョイントには, 制御トルクが加わるものと する.

仮定 3. 壁は等価な質量一バネーダンパー系であり, 変 位は壁の法線方向のみとする.

仮定 4. 衝突による力は, ポインターの壁への食い込み によって生じるものとし, Hertz 型の力に減衰効果を表 すパラメータを乗じたものとしてモデル化尚する.

仮定 5. 衝突による力は正（打互いに反発する力を及ぼ 乙合う状態）のみとし，方向は壁の法線方向とする. ま た, 壁とポインタとの摩擦は一般に衝突による力と比べ て無視できるほど小さく、ここでは考慮しないものとす る.

\section{2 運動方程式}

マニピュレータおよび壁について運動方程式をたて る.

2.2.1 マニピュレーレの運動方程式

マニピュレータの運動方程式はラグランジェの方法に

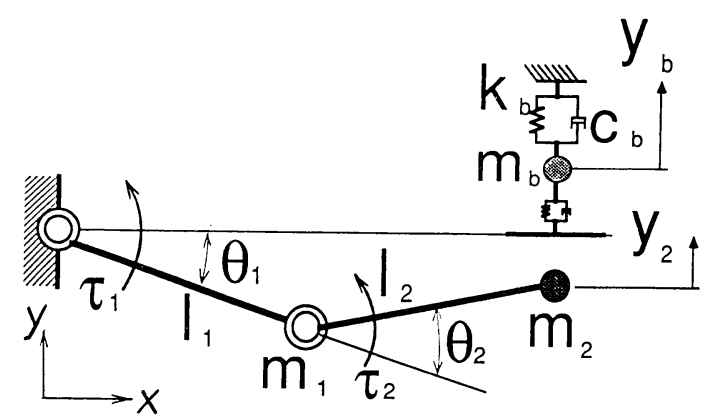

Fig. 1 Mathematical Model

よって求める.

運動エネルギーKとポテンシャルエネルギーTからラ グランジアンLを定義する.

$$
\begin{gathered}
K=\frac{1}{2} m_{1}\left(\dot{x}_{1}^{2}+\dot{y}_{1}^{2}\right)+\frac{1}{2} m_{2}\left(\dot{x}_{2}^{2}+\dot{y}_{2}^{2}\right) \\
T=0 \\
L=K-T \\
=K
\end{gathered}
$$

ここで, $m, x, y$ は各質点についての質量, $x$ 座標, $y$ 座標で, 添字字 1，2 はリンクの番号を示している. ま た， $x_{i}, y_{\imath}$ をりンクの相対角度で表すと以下のようにな る.

$$
\begin{gathered}
x_{1}=l_{1} \cos \theta_{1} \\
y_{1}=l_{1} \sin \theta_{1} \\
x_{1}=l_{1} \cos \theta_{1}+l_{2} \cos \left(\theta_{1}+\theta_{2}\right) \\
y_{1}=l_{1} \sin \theta_{1}+l_{2} \sin \left(\theta_{1}+\theta_{2}\right) \\
\dot{x}_{1}=-l_{1} \sin \theta_{1} \cdot \dot{\theta}_{1} \\
\dot{y}_{1}=l_{1} \cos \theta_{1} \cdot \dot{\theta}_{1} \\
\dot{x}_{2}=-l_{1} \sin \theta_{1} \cdot \dot{\theta}_{1}-l_{2} \sin \left(\theta_{1}+\theta_{2}\right) \cdot\left(\dot{\theta}_{1}+\dot{\theta}_{2}\right) \\
\dot{y}_{1}=l_{1} \cos \theta_{1} \cdot \dot{\theta}_{1}+l_{2} \cos \left(\theta_{1}+\theta_{2}\right) \cdot\left(\dot{\theta}_{1}+\dot{\theta}_{2}\right)
\end{gathered}
$$

ここで, $l_{1}, l_{2}$ はリンク長さ， $\theta_{1}$ は第 1 リンクと $x$ 軸 との角度, $\theta_{2}$ は第 1 リンクと第 2 リンクとの相対角度で ある.また, $\theta_{1}=\theta_{2}=0$ のとき, マニピュレータは自然 状態となり, 自然状態の壁と接触力 0 の状態で接する.

(1)，(3) 式に（8）から（11）式を代入して整理する と

$$
\begin{aligned}
L= & \frac{1}{2}\left(m_{1}+m_{2}\right) l_{1}{ }^{2} \dot{\theta}_{1}^{2}+\frac{1}{2} m_{2}\left\{l_{2}{ }^{2}\left(\dot{\theta}_{1}+\dot{\theta}_{2}\right)^{2}\right. \\
& \left.+2 l_{1} l_{2} \dot{\theta}_{1}\left(\dot{\theta}_{1}+\dot{\theta}_{2}\right) \cos \theta_{2}\right\}
\end{aligned}
$$

ラグランジアン $L$ から一般化力 $q_{i}$ は次式で定義され る.

$$
\frac{d}{d t}\left(\frac{\partial L}{\partial \theta_{i}}\right)-\frac{\partial L}{\partial \theta_{i}}=q_{i} \quad(i=1,2)
$$

ここで， $q_{i}$ は仮想仕事の原理を用いて次式のように定 義できる. 


$$
\begin{gathered}
q_{1}=\tau_{1}-f_{w}\left\{l_{1} \cos \theta_{1}+l_{2} \cos \left(\theta_{1}+\theta_{2}\right)\right\} \\
q_{2}=\tau_{2}-f_{w} l_{2} \cos \left(\theta_{1}+\theta_{2}\right)
\end{gathered}
$$

ただし， $\tau_{1}, \tau_{2}$ は第 1 リンク，第 2 リンクのアクチュ エータ制御入力で, その制御則は (16), (17) 式で表す. また， $f_{w}$ は衝突力で (18) 式3)で表す.

$$
\begin{gathered}
\tau_{1}=-K_{p 1} \theta_{1}-K_{v 1} \dot{\theta}_{1} \\
f_{2}=-K_{p 2} \theta_{2}-K_{v 2} \dot{\theta}_{2} \\
\begin{array}{cc}
(1+p \dot{u}) H u^{3 / 2}(u \geq 0 \text { かつ } \\
0 \quad \text { (その他 })
\end{array}
\end{gathered}
$$

ただし，

$$
u=y_{2}-y_{b}
$$

ここで， $p$ はエネルギー損失を表わすパラメータであ り，HはHertz の力の係数である．また $y_{2}, y_{b}$ は，壁 の法線方向に対するマニピュレータポインタ及び壁の変 位量である.

本論文では, 安定性の検討, あるいはシミュレーショ ンに際し, 衝突は有限の計測可能な時間で生じるものと して表すために衝突中の力もモデル化する必要があり, 既報の通りここでは最も妥当と思われる（18）式を採用 した。これより，仮定 5 から $u \geqq 0$ かつ $\dot{u} \geqq-1 / p$ を接 触状態，その他を非接触状態と考える. なお，ここで用 いた衝突モデルについての連続性や反発係数 $\boldsymbol{e}$ との関係 などは付録 1 に示す.（12)，(13）式からラグランジェの 方法にしたがって偏微分を行ない，(13), (14), (15) 式を 用いて整理すると，以下のようなマニピュレータの運動 方程式を得る。

$$
\begin{aligned}
& \ddot{\theta}_{1}=\frac{\alpha_{3} \beta_{2}-\alpha_{2} \beta_{3}}{\alpha_{1} \beta_{2}-\alpha_{2} \beta_{1}} \\
& \ddot{\theta}_{2}=-\frac{\alpha_{3} \beta_{1}-\alpha_{1} \beta_{3}}{\alpha_{1} \beta_{2}-\alpha_{2} \beta_{1}}
\end{aligned}
$$

$こ こ て ゙$

$$
\begin{aligned}
& \alpha_{1}=\left(m_{1}+m_{2}\right) l_{1}{ }^{2}+m_{2} l_{2}{ }^{2}+2 m_{2} l_{1} l_{2} \cos \theta_{2} \\
& \alpha_{2}=m_{2} l_{2}^{2}+m_{2} l_{1} l_{2} \cos \theta_{2} \\
& \alpha_{3}=m_{2} l_{1} l_{2}\left(\dot{\theta}_{1}+\dot{\theta}_{2}\right) \cos \theta_{2} \cdot \dot{\theta}_{2} \\
& -f_{w}\left\{l_{1} \cos \theta_{1}+l_{2} \cos \left(\theta_{1}+\theta_{2}\right)\right\}+\tau_{1} \\
& \beta_{1}=m_{2} l_{2}^{2}+m_{2} l_{1} l_{2} \cos \theta_{2} \\
& \beta_{2}=m_{2} l_{2}^{2} \\
& \beta_{3}=-m_{2} l_{1} l_{2} \dot{\theta}_{2}^{2} \cos \theta_{2}-f_{w} l_{2} \cos \left(\theta_{1}+\theta_{2}\right)+\tau_{2}
\end{aligned}
$$

以上でマニピュレータの運動方程式は求まった.

2.2.2 壁の運動方程式

壁の局部変形を表す運動方程式は次のようになる.

$$
m_{b} \ddot{y}_{b}=-k_{b} y_{b}-c_{b} \dot{y}_{b}+f_{w}
$$

ここで, $m_{b}, k_{b}, c_{b}$ は各々壁の等価な質量, バネ定数,

減衰定数である.

\section{3. 衝突を含む系の安定性}

系の安定性はリアプノフの直接法によって判定する. （29）式のように非線形スカラー関数を定義する. 物理 的には質量によって蓄えられるェネルギーと, 制御入力, 衝突力のバネ作用によるエネルギーに対応する.

$$
\begin{aligned}
& V=\frac{1}{2}\left(m_{1}+m_{2}\right) l_{1}{ }^{2} \dot{\theta}_{1}^{2}+\frac{1}{2} m_{2}\left\{l_{2}^{2}\left(\dot{\theta}_{1}+\dot{\theta}_{2}\right)^{2}\right. \\
& \left.+2 l_{1} l_{2} \dot{\theta}_{1}\left(\dot{\theta}_{1}+\dot{\theta}_{2}\right) \cos \theta_{2}\right\} \\
& +\frac{1}{2} m_{b} \dot{y}_{b}{ }^{2}+\frac{1}{2} K_{p 1} \theta_{1}{ }^{2}+\frac{1}{2} K_{p_{2}} \theta_{2}{ }^{2} \\
& +\frac{1}{2} k_{b} y_{b}{ }^{2}+\Delta k \cdot u^{2} \\
& \text { ここで } \\
& \Delta k=\left\{\begin{array}{c}
a H u^{1 / 2}(u \geq 0 \text { かつ } \dot{u} \geq-1 / p \text { のとき) } \\
0 \quad \text { (その他) }
\end{array}\right.
\end{aligned}
$$

ただし， $a$ は正の定数であり，制御すべき変数ではな い.もし（29）式のスカラー関数がリアプノフ関数とな るような定数 $\boldsymbol{a}$ が存在すれば系の安定が論じられる.

スカラー関数 $V$ について考えると, 運動方程式の導出 過程を見れば，右辺の第 1 項と第 2 項はリンクの運動エ ネルギーであるから非負. また, それ以外の項は完全平 方の形をしており非負.よって，(30）式より

$$
V\left\{\begin{array}{l}
=0\left(\theta_{1}=\dot{\theta}_{1}=\theta_{2}=\dot{\theta}_{2}=y_{b}=\dot{y}_{b}=0\right. \text { のとき) } \\
>0 \quad \text { (その他) }
\end{array}\right.
$$

次に，Vの微係数について考える.（29）式を時間で微分 し，(20) 式から（28）式を代入して整理すると（32）式の ようになる。

$$
\begin{gathered}
\dot{V}=-K_{v 1} \dot{\theta}_{1}{ }^{2}-K_{v 2} \dot{\theta}_{2}{ }^{2}-c_{b} \dot{y}_{b}{ }^{2}-\left(\dot{y}_{2}-\dot{y}_{b}\right) f_{w} \\
+\frac{5}{2} \Delta k u \dot{u}
\end{gathered}
$$

以下，非接触状態と接触状態を別々に考える.

\section{1 非接触状態の場合}

このとき, $u<0$ または $\dot{u}<-1 / p$ で

$$
f_{w}=0, \Delta k=0
$$

このとき，(32）式は（34）式となる.

$$
\begin{gathered}
\dot{V}=-K_{v 1} \dot{\theta}_{1}{ }^{2}-K_{v 2} \dot{\theta}_{2}{ }^{2}-c_{b} \dot{y}_{b}{ }^{2} \\
\text { いま, } K_{v 1}, K_{v 2} \text { と } c_{b} \text { とが正であれば } \\
\dot{V} \leq 0
\end{gathered}
$$

\section{2 接触状態の場合}

このとき $u \geqq 0$ かつ $\dot{u} \geqq-1 / p$ で

$$
\begin{gathered}
f_{w}=(1+p \ddot{u}) H u^{3 / 2} \\
\Delta k=a H u^{1 / 2}
\end{gathered}
$$

このとき，(32）式は（37）式となる.

$$
\begin{gathered}
\dot{V}=-K_{v 1} \dot{\theta}_{1}{ }^{2}-K_{v 2} \dot{\theta}_{2}{ }^{2}-c_{b} \dot{y}_{b}{ }^{2}-p H u^{3 / 2} \dot{u}^{2} \\
-\left(1-\frac{5}{2} a\right) p H u^{3 / 2} \dot{u}
\end{gathered}
$$

いま, $K_{v 1}, K_{v 2}$ と $c_{b}$ とが正で,（38）式が成り立てば 
（39）式が満足される.

$$
\begin{aligned}
& a=\frac{2}{5} \\
& \dot{V} \leq 0
\end{aligned}
$$

以上を整理すると, フィードバックゲイン及び定数 $a$ に対して

$$
\left.\begin{array}{l}
K_{p 1}>0, \quad K_{p 2}>0 \\
K_{v 1}>0, \quad K_{v 2}>0, \quad a=\frac{2}{5}
\end{array}\right\}
$$

のときVはリアプノフ関数となり，そうなるような定 数 $a$ が存在する.

よって, 衝突を含むFig.1 の系がリアプノフの意味で 安定であることが示された. また（34）式と（37）式とを

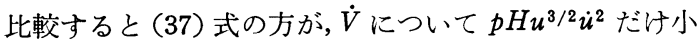
さい.この項は衝突による項なので, 衝突が安定化作用 を持つことが分かる.このことから，本論文で扱ってい るような問題のように接触の避けられない位置決めでは, 衝突を積極的に作用する制御も考えるべきであることが 分かる.なお，リアプノフ関数では連続性や微分可能が 問題となるが, 付録 2 に詳述のよらに, ここでは, 関数 の性質上問題無く取り扱うことができる.

\section{4. シミュレーション結果と考察}

衝突を含む安定制御について, 以下シミュレーション によりその過渡状態について検討する。

3 章の安定性解析で扱った制御則は，一般によく制御 に用いられる状態フィードバックの特殊な例であると言 える. 即ら, 一般的な状態フィードバックは, 状態变数 が四つで制御入力が二つであるから， 2 行 4 列のフィー ドバックゲイン行列を用いて（41）式の様に表せる.

$$
\begin{aligned}
& \tau=\left\{\begin{array}{l}
\tau_{1} \\
\tau_{2}
\end{array}\right\}=\left[\begin{array}{ll:ll}
k_{p 11} & k_{p 12} & k_{v 11} & k_{v 12} \\
k_{p 21} & k_{p 22} & k_{v 21} & k_{v 22}
\end{array}\right]\left\{\theta_{1} \theta_{2} \dot{\theta}_{1} \dot{\theta}_{2}\right\}^{T}
\end{aligned}
$$

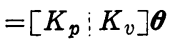

ここで, ベクトルは各々制御トルクベクトル, 状態ベク トルであり, $K_{p}, K_{v}$ はフィードバックゲインの部分行 列である.（16)，(17）式で表わされる3 章での制御則は, このうち $K_{p}, K_{v}$ の対角要素のみを非零の数としたもの で（42）式のように表したものである.

$$
\boldsymbol{\tau}=\left[\operatorname{diag} K_{p}: \operatorname{diag} K_{v}\right] \boldsymbol{\theta}
$$

この制御は, ローカルフィードバック制御の比較的簡単 な例であり, 各リンクは独立に制御されるものと考えら れる。

シミュレーションでは，(41) 式で表されるような, 制 御についても考えてみる.

\section{1 解 法}

（20）式から（28）式の運動方程式を 4 次のルンゲクッ 夕法で解く.
ただし、マニピュレータリンクと壁とは独立な系であ ると考える.この 2 つの系が接触した場合には相対変位 と相対速度とから（18）式により決定される衝突力がお 互いに㗢くだけで機械的につながってはいないものと考 える. また，ここでの手法では, 接触, 非接触の繰り返 しがあっても計算をすることができる.

\section{2 境界条件}

接触・非接触の判別は, ポインターとの壁の法線方向 相対変位 $u$ と相対速度 $\dot{u} に よ り$ 決定する.（2.2 節参照） このうち特に接触と非接触の状態の変化については, ル ンゲクッタ法による各々の時間刻みの前後の状態量 $(u$, u）から接触か否かの状態を見て決める. 例えば， ある 時間刻みの前で非接触状態 $(u<0$ または $\dot{u}<-1 / p)$ た ったものが，時間刻みの後の計算結果では接触状態 $(u \geqq 0$ かつ $\dot{u} \geqq-1 / p)$ になっていれば，その時間刻みの ぞこかで接触するはずである，そこで，ての時間刻みの 中の接触する時刻 $t_{c}$ を時間刻及前後の $u, \dot{u}$ 線から線形 補間により求め, この時刻 $t_{c}$ における全状態量（例え ば $\left.y_{2}, \dot{y}_{2}, y_{b}, \dot{y}_{b}\right)$ を時間刻みと $t_{c}$ の比から求める.こ の, 時刻 $t_{c}$ の状態を初期条件と置き直して $t_{c}$ 以降の時 間刻又の残り分を計算し，順次々の次の時刻へ計算を進 めていく. 非接触状態とする場合は接触する場合の逆に 考え, ある時間刻みの前の状態が接触で後の状態が非接 触であれば，その時間刻みの中で非接触となる時刻を求 めてこの状態量を初期条件としてルンゲクッタ法の計算 を進める．全体の計算は，この状態判別を各々の時間刻 みで行っていく，ただし，接触状態と非接触状態の違い は（48）式の $f_{w}$ が 0 か否かの違いだけである.

\section{4,3 計算結果}

Table 1 にシミュレーションに用いたハララメータを示 す.また，Fig. 2 から Fig. 8 にシミュレーション結果 を示す. ここで, No. 1 から No. 7 の計算は次の条件と なっている. (Table 1 参照)

これらのシミュレーションによって, 衝突を含むマニ ピュレータの制御のらち, 衝突の安定性に対する影響, フィードバックゲインの過渡応答に対する影響, 更に, 押し付け力の系に対する影響などがわかる.

No. 1 一般的な状態フィードバック制御を行った場合 の応答例 (Fig. 2). この場合, 制御は（41）式に表され るようにフィードバックゲインの部分行列が対角行列で ない場合を考えており, 安定性は保証されていないが, ここでは安定に制御されている．安定な制御を行う為の フィードバックゲインを選ぶためには，適当な範囲内で の試行錯䛊が必要である. また，図の中でマニピュレー タの方が壁よりも大きくなっているのはマニピュレータ が壁に食い込んでいる状態を示している（以下同じ）。 
福田敏男細只英実

No. 2 一般的な状態フィードバック制御の別の応答例

(Fig. 3). この場合, 基本的には No.1 のヶースと同じ であるが，(41）式で非対角項である各リンク間の干渉項 の值, 特に速度に関するフィードバックゲインを大きく した.ここでは，不安定な応答を示している. No. 1 と No. 2 の二つのケースを比較すると，(41）式で表される 制御については応答变更の為のハイゲイン化が, 安定性 の面からある程度制限を受けること，またフィードバッ クゲインのチューニングがかなり微妙なことが分かる.

No.3 No.2 のシミュレーションケースで, 壁との衝突 を生じず,マニピュレータ単体を同じ制御則と初期条件 で制御した場合の応答 (Fig. 4). 同じ制御を行っても不 安定な応答を示さない. 即ち、マニピュレータ単体では 不安定でないように制衙されていても衝突を生じること により, 挙動が不安定になり,一般的な状態フィードバ ック制御では, 衝突が系を不安定化させる要素として働 くこともあることがわかる.このことは, マニピュレー 夕単体に関する優れた制御も, 衝突を生じるような系全 体の制御としては，必ずしも良い制御であるとは限らな いことを示している.

No.4（42）式に表されるようにフィードバックゲイン 行列の対角成分のみが非零となるような線形フィードバ ック制御を行った場合の応答 (Fig. 5). これは, マニピ ュレータの各リンクについてローカルフィードバック制 御を行っていることを意味している.ここでの制御では， 対角成分は No. 1 から No. 3 と同じとしている.このシ ミュレーションは第 3 章で検討した制御を行っているの で, リアプノフの安定性解析のとおり安定な挙動を示し ている.これにより, 簡単な線形フィードバックによる
制御でも衝突を含む非線形マニピュレータの安定な押し 付けが可能であることが分かる. ただ，No. 1 と比較す ると同じ時刻における振幅は若干大きい.

No. 5 No. 4 と同じマニピュレータで角度に対するフィ ードバックゲインを大きくした場合の応答. (Fig. 6) 角 度フィードバックゲインを大きくすると応答は速くなる が，収束性が悪くなる．これは, 衝突を含んでいない、 ニピュレータを制御する場合と一致する.（42）式で表さ れるよらな線形フィードバックに於けるゲイン調整では, 第 3 章の結果からこの制御則を使う場合は, 応答改善の ためにハイゲイン化しても安定性は保証されているので, 衝突を含まないマニピュレータと同様の考えで行なえば 良いことが分かる.

以上から，一般的な非線形な多リンク系の状態フィー ドバック制卸で衝突といら現象が系に含まれる場合には, 系が非線形であっても, 線形のローカルフィードバック 制御によって各リンクを独立に制御した方が，安定性の 面でより良いとも考えられる．また，第 3 章の結果も考 えるとき，ローカルフィードバックによる制御則ではゲ インを負にしなければ必ず系が安定であることが保証さ れており，ロバスト性についてもローカルフィードバッ ク制御の方が有利である.

また第 3 章では，系の応答に対して衝突が安定化要素 として働くことがあるといらことを示したが，このこと についてシミュレーションにより検討してみる.

No. 6 非常に理想的な状態で, 減衰の項を全て 0 とし た系の応答 (Fig. 7). ここでの制御としては減衰効果の ある相対角速度に対するフィードバックは考えず，相対 角度のフィードバックのみとした，系としては減衰が無

Table 1 Parameters for the Simulations

\begin{tabular}{|c|r|r|r|r|r|r|r|}
\hline CASE NO. & \multicolumn{1}{|c|}{1} & \multicolumn{1}{|c|}{2} & \multicolumn{1}{|c|}{3} & \multicolumn{1}{c|}{4} & \multicolumn{1}{c|}{5} & \multicolumn{1}{c|}{6} & \multicolumn{1}{c|}{7} \\
\hline $\mathrm{m} 1$ & 2.0 & 2.0 & 2.0 & 2.0 & 2.0 & 2.0 & 2.0 \\
$\mathrm{~m} 2$ & 1.0 & 1.0 & 1.0 & 1.0 & 1.0 & 1.0 & 1.0 \\
11 & 1.0 & 1.0 & 1.0 & 1.0 & 1.0 & 1.0 & 1.0 \\
12 & 1.0 & 1.0 & 1.0 & 1.0 & 1.0 & 1.0 & 1.0 \\
$\mathrm{mb}$ & 10.0 & 10.0 & - & 10.0 & 10.0 & 10.0 & 10.0 \\
$\mathrm{Rb}$ & 100.0 & 100.0 & - & 100.0 & 100.0 & 100.0 & 100.0 \\
$\mathrm{cb}$ & 0.3 & 0.3 & - & 0.3 & 0.3 & 0.0 & 0.0 \\
$\mathrm{H}$ & 10000.0 & 10000.0 & - & 10000.0 & 10000.0 & 10000.0 & 10000.0 \\
$\mathrm{p}$ & 0.3 & 0.3 & - & 0.3 & 0.3 & 0.0 & 3.0 \\
$\mathrm{Kp} 11$ & 5.0 & 5.0 & 5.0 & 5.0 & 10.0 & 5.0 & 5.0 \\
$\mathrm{Kp} 12$ & 3.0 & 3.0 & 3.0 & 0.0 & 0.0 & 0.0 & 0.0 \\
$\mathrm{Kp} 21$ & 3.0 & 3.0 & 3.0 & 0.0 & 0.0 & 0.0 & 0.0 \\
$\mathrm{Kp} 22$ & 5.0 & 5.0 & 5.0 & 5.0 & 10.0 & 5.0 & 5.0 \\
$\mathrm{Kv} 11$ & 2.0 & 2.0 & 2.0 & 2.0 & 2.0 & 0.0 & 0.0 \\
$\mathrm{Kv} 12$ & 1.0 & 3.0 & 3.0 & 0.0 & 0.0 & 0.0 & 0.0 \\
$\mathrm{Kv} 21$ & 1.0 & 3.0 & 3.0 & 0.0 & 0.0 & 0.0 & 0.0 \\
$\mathrm{Kv} 22$ & 2.0 & 2.0 & 2.0 & 2.0 & 2.0 & 0.0 & 0.0 \\
\hline
\end{tabular}


く, 復元力のみが存在するので物理的には臨界安定であ ることが予想されるが，その通りの結果となっており， 応答は減衰も発散もせずに周期的に続いていく.

No. 7 マニピュレータ本体と壁自身による減衰の項をす べて 0 とし, 衝突のみに減衰効果を持たせた $(p, c v>0)$ 場合の応答 (Fig. 8). No.6 と同様で, 制御としては角 速度のフィードバックは考えず, 角度フィードバックの みとしたＮNo.6 と比較して明らかに運動が収束する傾 向を示している.これより, 減衰の無いようなマニピュ レータや対象物を含も系でもエネルギー散逸を含む衝突 $(p, c v>0)$ により安定化することができ, 衝突が安定化 作用を持っていることがわかる. このことは, 第 3 章に おけるリアプノフの方法を用いた安定性解析の結果と一 致する. 従って, 第 1 章でも述べた通り, 第 3 章で示し たような制御則では衝突を利用することによって, 位置 決め制御を容易にすることができることが分かる.
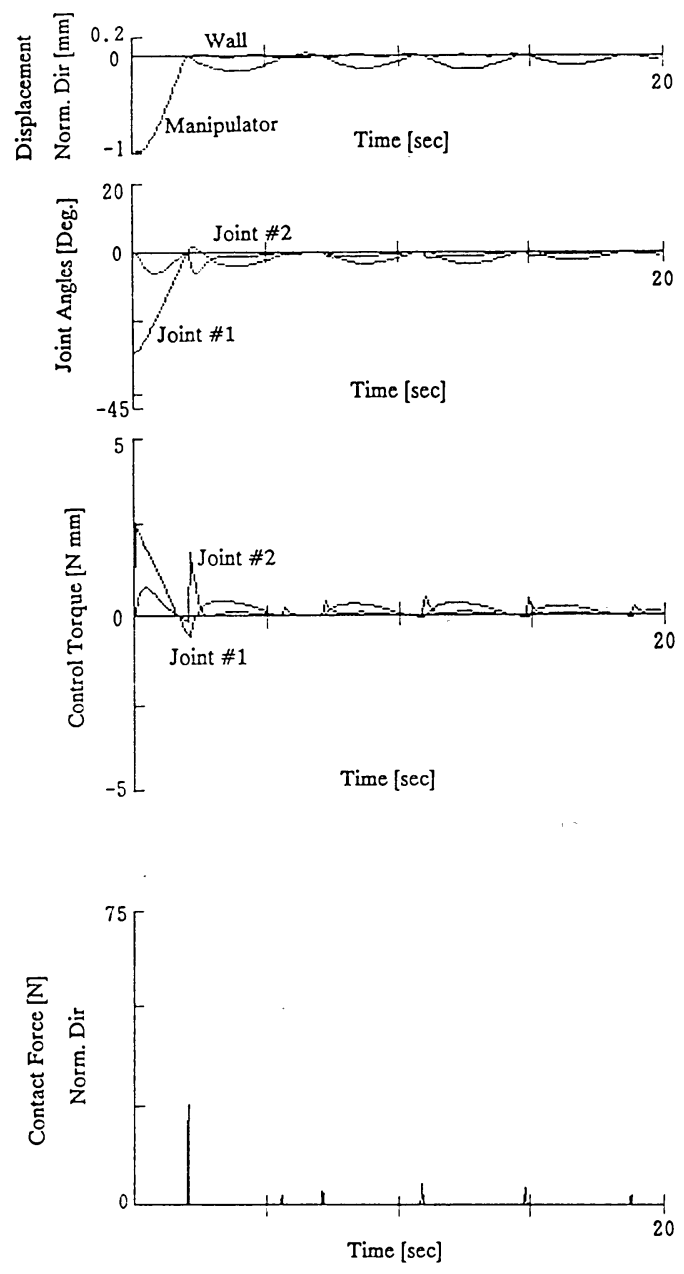

Fig. 2 Linear State Feedback (coupled $\# 1$ )

\section{5. ま と め}

本論文では衝突を含む多リンクマニピュレータの押し 付け動作につき，第 2 章でモデル化とその動特性方程式 の導出を行い, 第 3 章ではリアプノフの直接法によって 理論的に娭討し，また第 4 章ではシミュレーションによ ってその過渡状態について検討した. この結果, 衝突を 含み, マニピュレータ自体が非線形であるよらな多りン ク系であってもリアプノフの直接法によって安定性を論 じることが可能であることが示された，また，衝突は系 を安定化させる現象であり, 線形ローカルフィードバッ ク制御によっても衝突を含む系の安定な押し付け制御が 可能であることが確認された，また，衝突を利用した位 置決め制御が可能であることも示された.

付録 1 衝突力のモデルついての説明

ここで採用したモデルはヘルツの力 $H u^{3 / 2}$ に, 減衰項
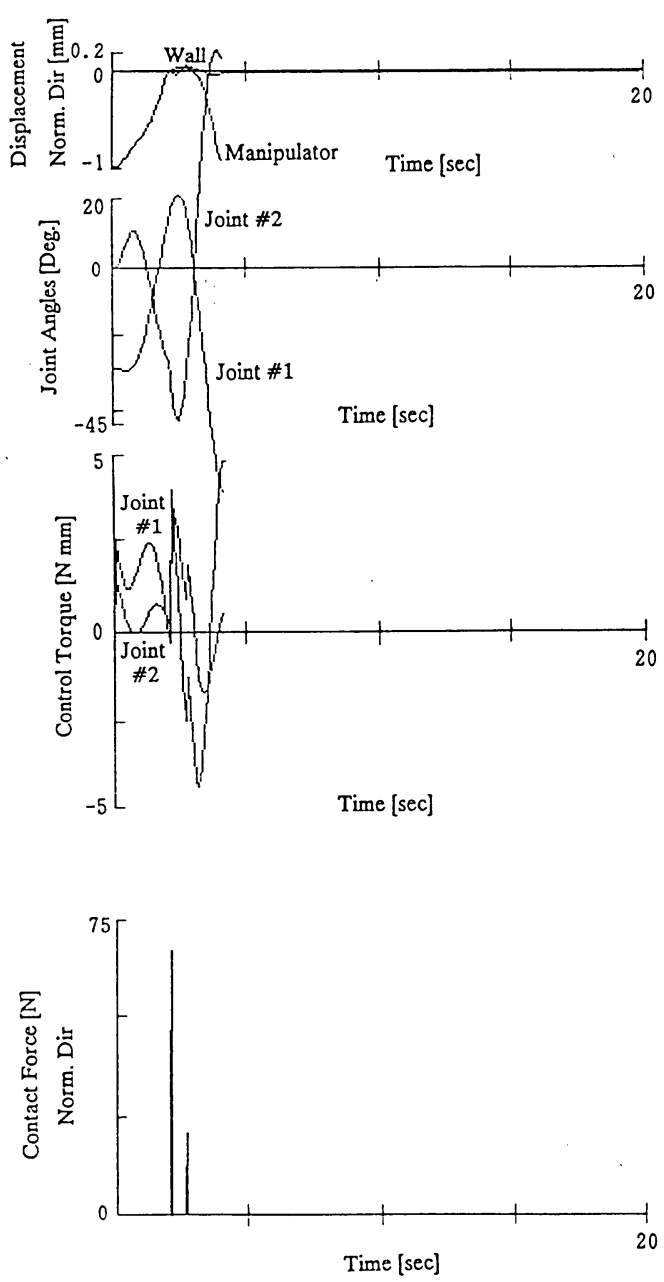

Fig. 3 Linear State Feedback (Coupled $\$ 2$ ) 
$(1+p u)$ を乗じた形で表される，この時考えねばならな いのは, 運動方程式の連続性と, いわゆる反発係数 $e$ と の関係についてである.

まず，連続性についてであるが，この衝突モデルにつ いて接触条件は $u \geqq 0, \dot{u} \geqq-1 / p$ である. いま, 衝突を 時間と相対変位に対して考えると，

(a) 常に $\dot{u} \geqq-1 / p$ のとき
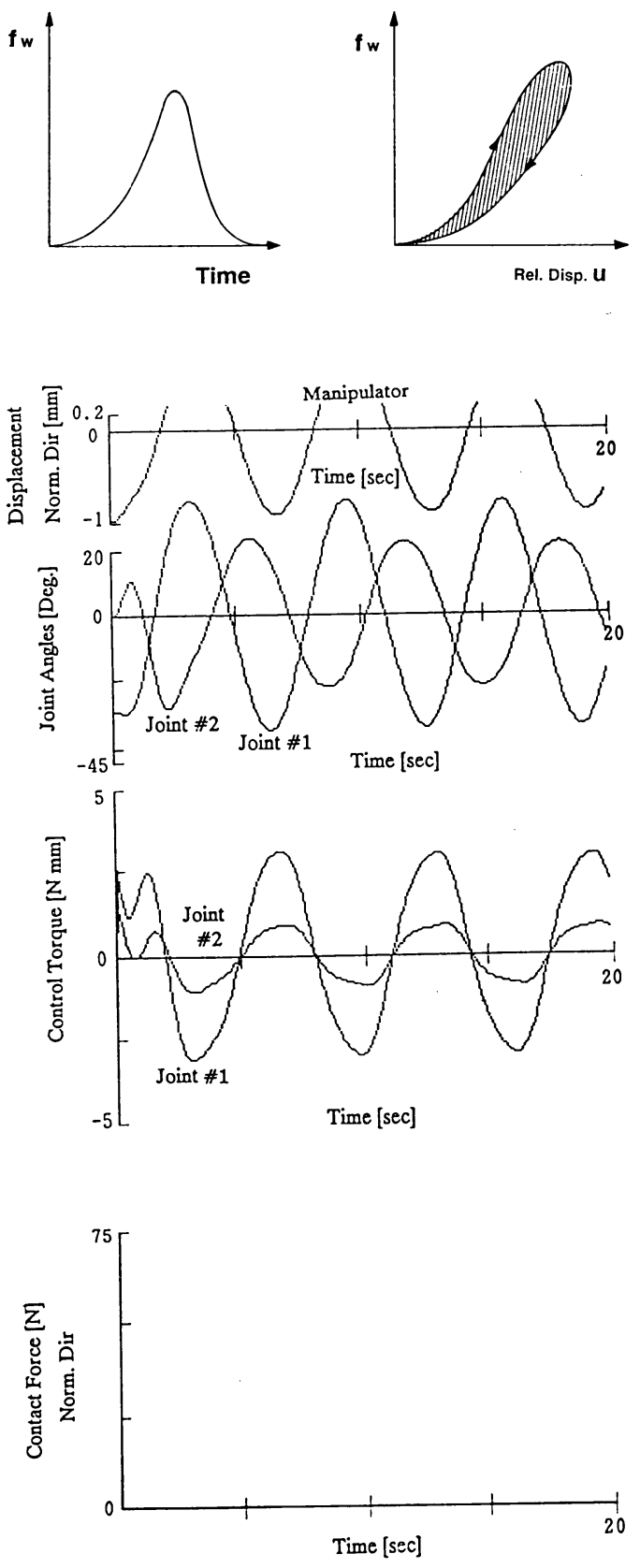

Fig. 4 No Wall with Linear State Feedback $\$ 2$
福田敏男細貝英実

(b) $\dot{u}<-1 / p$ となる場合があるとき
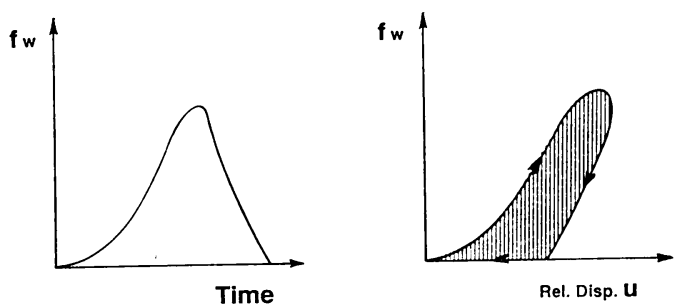

いずれの場合も衝突力は連続であることが分かる.な お, 物理的に $f_{w}-u$ のグラフにおける斜線部がエネル ギー損失であり，pが大きいときにこの部分の面積が大 きくなるので, pがェネルギー損失のパラメータとなる. 運動方程式では, この力の連続性から, 時間と角度およ び角速度についてジャンプは存在せず，リプシッッ条件 も成立することが分かる。
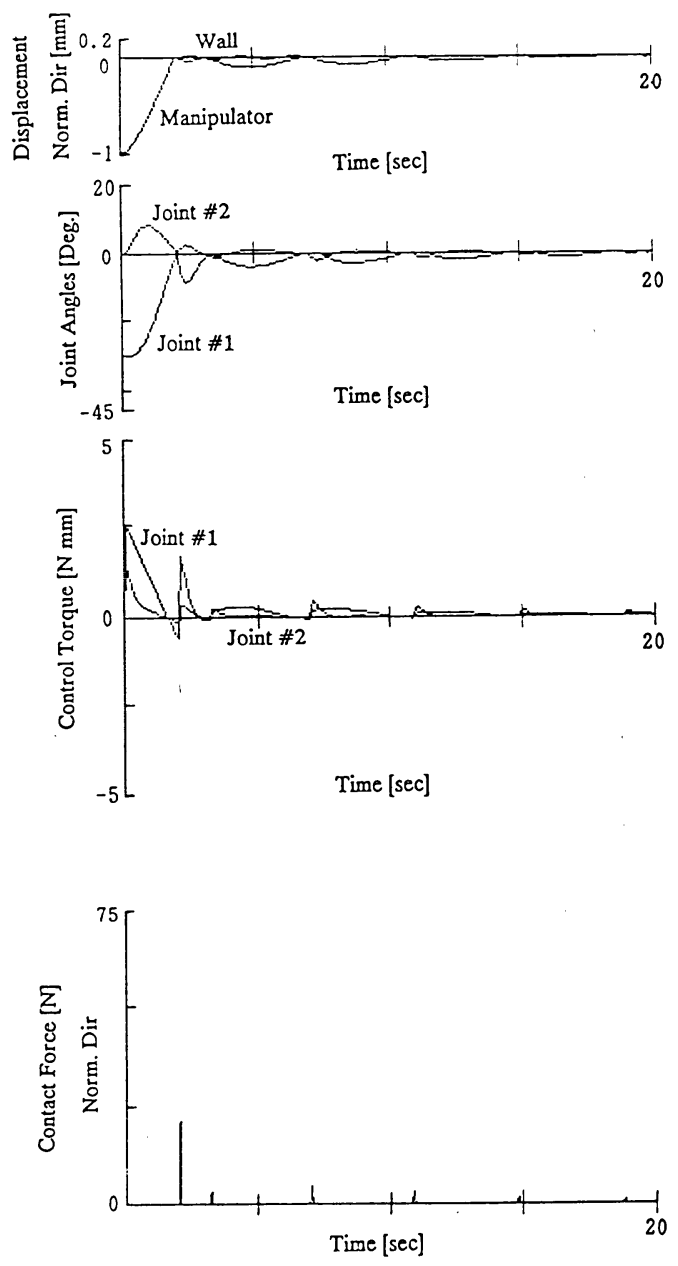

Fig. 5 Decoupled State Feedback 
次に反発係数 $\boldsymbol{e}$ との関係であるが，これは， $p$ と衝突 速度 $v_{0}$ を用い, 衝突から最大局部变位, またここから 反発までについて加速度を積分すると次式のように表す ことができる.

$$
e=\frac{1}{p v_{0}}-\left(1+\frac{1}{p v_{0}}\right) \exp \left\{-(1+e) p v_{0}\right\}
$$

外力が無い場合, 反発の最大速度は一 $-e v_{0}$ であるが, $\dot{u}=-e v_{0} \geqq-1 / p$ が常に成立する条件は, $e \leqq 1 / p v_{0}$ であ る. 上記の $e$ と $p$ の関係式から, この条件は常に成立す る. 従って, $\dot{u}<-1 / p$ となるのは, 外力がある場合に 限られる、制御系では, 制御力がこれに当たり, この場 合, 制御力は衝突力に比べて大きい必要がある.これは, 物理的には柔らかいものに対するゆっくりとした接触で あり，2つの物体が局部变形をして食い込んで復元しよ らとしている時に, 制御によって復元速度よりも速く引 っ張られるような状態に対応する，よって通常行なわれ
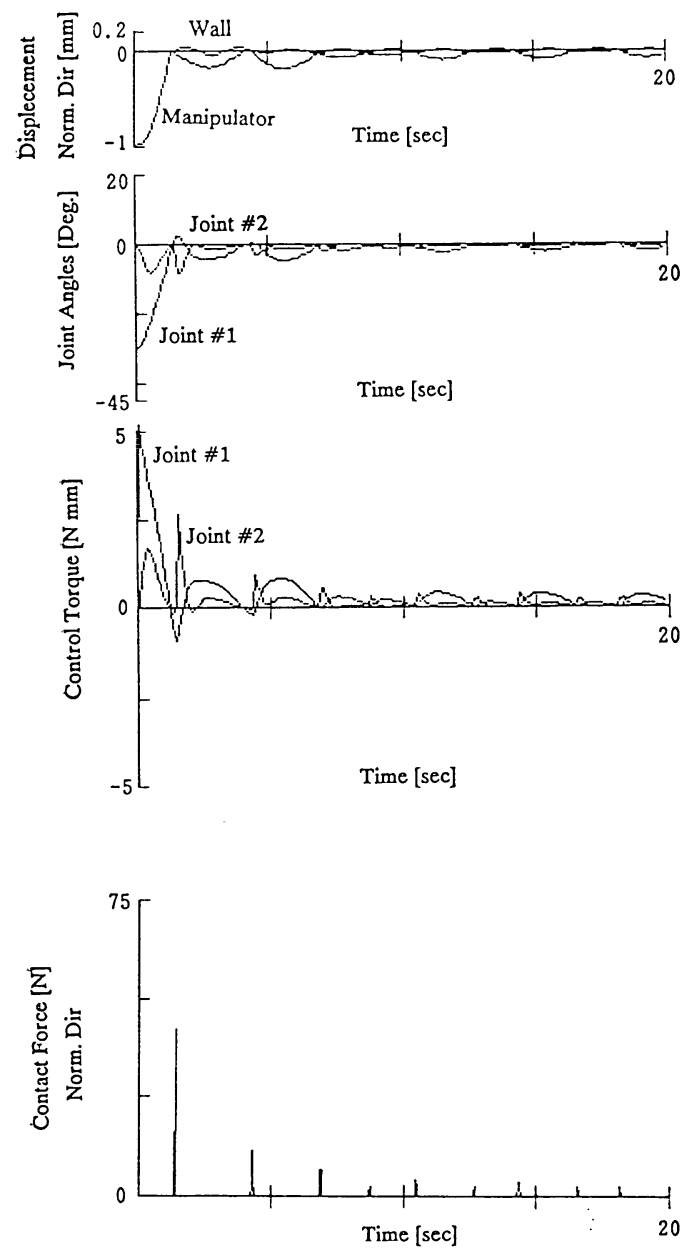

Fig. 6 Decoupled Feedback with Larger Angular Gains
るような金属同志の衝突ではほとんどありえない、

\section{付録 2 リアプノフ関数の連続性について}

本論文では, ある意味で二つのスカラー関数を接触状 態と非接触状態とで切り替えて使っている．本件につい て次のように考える。

衝突を論じる場合, 本論文のモデルではへルッの力の 係数 $H$ と土ネルギー損失パラメータ $\mathrm{p}$ とが大変重要とな る. $H$ は、いわばマニピュレータと壁との間の局部变形 に関わるバネ定数と同じようなものであり， $p$ は街突時 の加速と減速の力の履歴の違いからくる減衰定数之同じ 様なものである、ただし，いま考えている接触または非 接触の状態判別ではpの方がより重要である. そこで, このpに着目してリアプノフ関数を考えてみる.ここで, 物理的に考克, 減衰が負になるのは考えないものとして, pは非負であるものとする。

（18）式の定義から、リアプノフ関数の等值線は困の
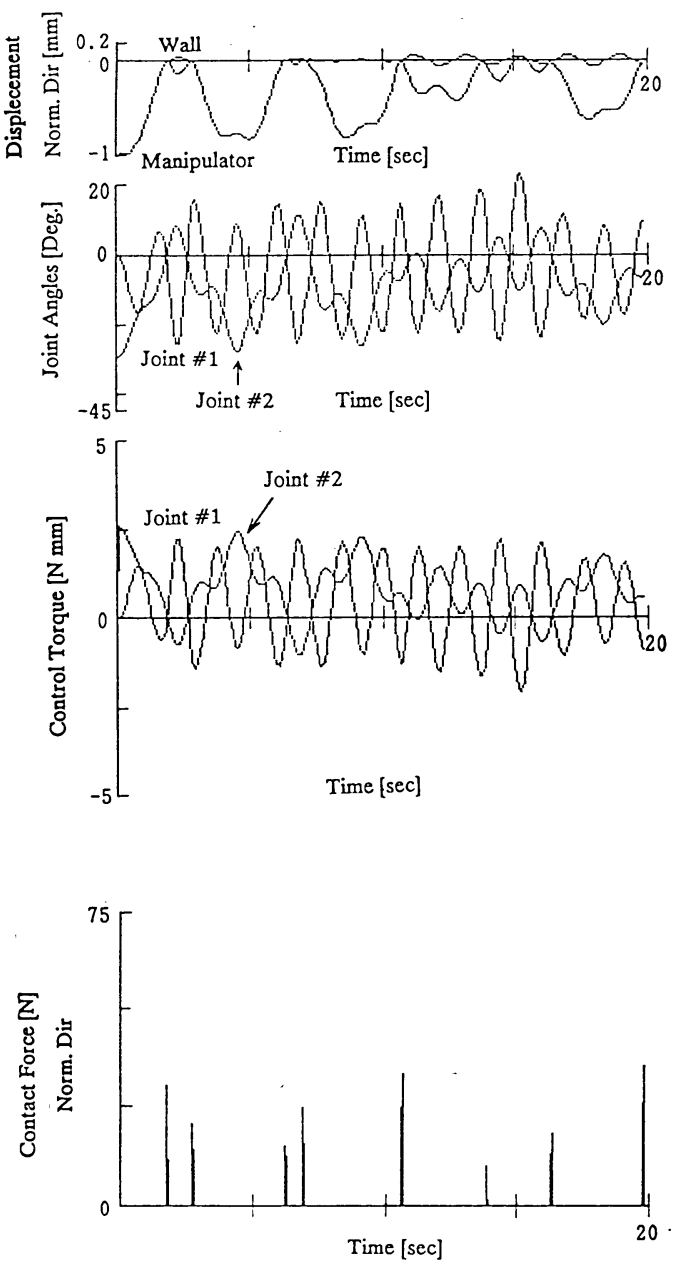

Fig. 7 No Damping (Decoupled) 

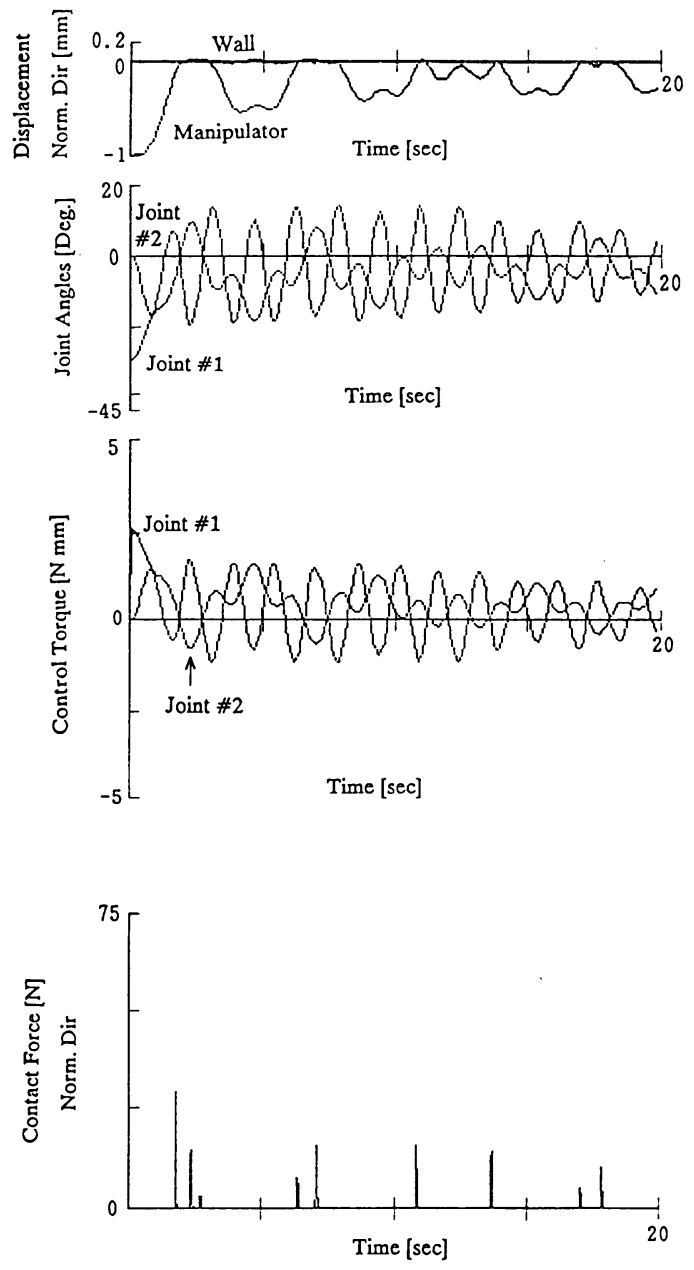

Fig. 8 No Damping except Collision (Decoupled)

Fig.a-1 のように表すことができる.いま，十分に減衰 が小さく，pが小さい場合を考えるとリアプノフ関数の 軌跡は Fig.a-2 のようになる。ここで，いくつかの閉 曲線があるが, 内側の閉曲線はスカラー関数が小さい值 を取ることを意味している．また，接触を表す等値線と

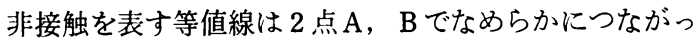
て扣り，衝突が生じるとき，軌跡は時計奋りとなる。こ
のとき,もしも系が安定ならば, 軌跡は原点に収束して 行き, 系の運動は平衝点で静止する.この場合は, リア プノフ関数が連続であり, 微分可能であることは明らか である.

しかしながら，減衰が大きく，即ちかがあまり小さく ない場合には少し違ってくる。この場合の等値線図は Fig. a-3 のようになる. いま，接触状態にある関数が， 点Cにおいて $\dot{u}=-1 / p$ の線と交差するものとすると， 衝突力のモデルの定義から, 接触状態が非接触状態に変 化する.このとき，スカラー関数では，いままであった 衝突を表す非負の項が無くなるので，この分内側へ值が ジャンプすることになる．しかも，軌跡は時計迴りであ るので, ジャンプの方向は点 Cから内側の点 $\mathrm{D} へ$ の方 向である. 即ち、リアプノフ関数が 2 点 $\mathrm{C}, \mathrm{D} て ゙$ 不連続 であっても関数值は常に減少することが明らかである. さらに, ある程度運動が遅くなり, 平衡点に近づいてく ると，もう $\dot{u}=-1 / p$ の影響を受けなくなり， Fig. a-2 で示されるような系と同様になり，連続性と微分可能性 が確保されるよらになる。

以上から，論文で示したリアプノフ関数の連続性に関 する妥当性が示された。

\section{文献}

1）正司・稲葉・福田・細貝，衝笑を含むマニピニレータの 安定制御（第 1 報：1 自由度マニピュレータの押し付け 制御の安定性), 日本機械学会論文集 C 編, 56-527, pp. 203-209 (1990).

2）正司・稲葉・福田・細貝，衝突を含むマニピュレータの 安定制御（第 2 報：2本の 1 自由度マニピュレータによ る物体把持)，日本機械学会論文集 C 編， 56-529, pp. 114-122 (1990).

3）藤田・服部，周期衝突振動における衝撃特性，日本機械 学会論文集C編, 45-395, pp. 738-746 (1979).

4）福田・北村・谷汇，対象物の動特性を考虑したグリッバ の適応ハイブリッド力制御方式, 日本ロボット学会誌, Vol.6, No.2, pp. 3-12.

5）正司・稻葉・福田・細貝，衝突を考虑したマニピュレー タの制卸（第 2 報， 2 本の 1 自由度マニピュレータによ る物体把持), 第28回 SICE 学術講演会予稿集, pp. 209210 (1989).

6）倉扑・原，磁気ばね動吸振器の作用について（衝突を伴 5場合の最適効果)，日本機械学会論文集 C編，45-399, pp. 1217-1224 (1979).

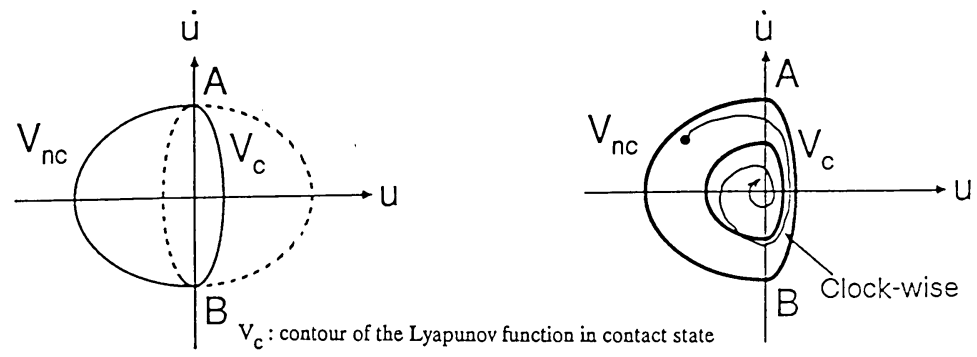

Fig. a-1 $V_{n c}$ : contour of the Lyapunov function in noncontact state
Fig. a-2

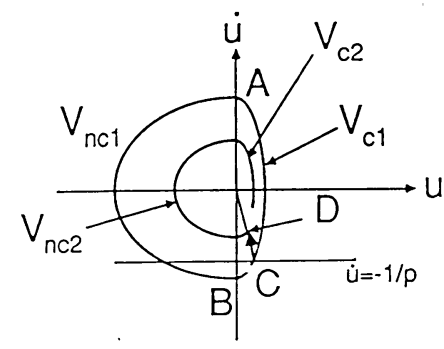

Fig. a-3 